\title{
Article
}

\section{Parental Education and Left Lateral Orbitofrontal Cortical Activity during N-Back Task: An fMRI Study of American Adolescents}

\author{
Shervin Assari ${ }^{1,2, *} \mathbb{C}$, Shanika Boyce ${ }^{3}{ }^{-}$, Mohammed Saqib ${ }^{4}$, Mohsen Bazargan ${ }^{1,5}$ and Cleopatra H. Caldwell ${ }^{3,6}$ \\ 1 Department of Urban Public Health, Charles R Drew University of Medicine and Science, \\ Los Angeles, CA 90059, USA; Mohsenbazargan@cdrewu.edu \\ 2 Department of Family Medicine, Charles R Drew University of Medicine and Science, \\ Los Angeles, CA 90059, USA \\ 3 Department of Pediatrics, Charles R Drew University of Medicine and Science, Los Angeles, CA 90059, USA; \\ ShanikaBoyce@cdrewu.edu (S.B.); cleoc@umich.edu (C.H.C.) \\ 4 Department of Health Behavior and Health Education, School of Public Health, University of Michigan, \\ Ann Arbor, MI 48104, USA; saqimoha@umich.edu \\ 5 Department of Family Medicine, University of California Los Angeles, Los Angeles, CA 90095, USA \\ 6 Center for Research on Ethnicity, Culture, and Health (CRECH), School of Public Health, \\ University of Michigan, Ann Arbor, MI 48104, USA \\ * Correspondence: assari@umich.edu; Tel.: +1-734-232-0445; Fax: +1-734-615-8739
}

Citation: Assari, S.; Boyce, S.; Saqib, M.; Bazargan, M.; Caldwell, C.H.

Parental Education and Left Lateral Orbitofrontal Cortical Activity during N-Back Task: An fMRI Study of American Adolescents. Brain Sci. 2021, 11, 401. https://doi.org/ 10.3390/brainsci11030401

Academic Editor: Valerio Santangelo

Received: 7 March 2021

Accepted: 19 March 2021

Published: 22 March 2021

Publisher's Note: MDPI stays neutral with regard to jurisdictional claims in published maps and institutional affiliations.

Copyright: (c) 2021 by the authors. Licensee MDPI, Basel, Switzerland. This article is an open access article distributed under the terms and conditions of the Creative Commons Attribution (CC BY) license (https:// creativecommons.org/licenses/by/ $4.0 /)$.
Abstract: Introduction. The Orbitofrontal Cortex (OFC) is a cortical structure that has implications in cognition, memory, reward anticipation, outcome evaluation, decision making, and learning. As such, OFC activity correlates with these cognitive brain abilities. Despite research suggesting race and socioeconomic status (SES) indicators such as parental education may be associated with OFC activity, limited knowledge exists on multiplicative effects of race and parental education on OFC activity and associated cognitive ability. Purpose. Using functional brain imaging data from the Adolescent Brain Cognitive Development (ABCD) study, we tested the multiplicative effects of race and parental education on left lateral OFC activity during an N-Back task. In our study, we used a sociological rather than biological theory that conceptualizes race and SES as proxies of access to the opportunity structure and exposure to social adversities rather than innate and non-modifiable brain differences. We explored racial variation in the effect of parental educational attainment, a primary indicator of SES, on left lateral OFC activity during an N-Back task between Black and White 9-10 years old adolescents. Methods. The ABCD study is a national, landmark, multi-center brain imaging investigation of American adolescents. The total sample was 4290 9-10 years old Black or White adolescents. The independent variables were SES indicators, namely family income, parental education, and neighborhood income. The primary outcome was the average beta weight for N-Back ( 2 back versus 0 back contrast) in ASEG ROI left OFC activity, measured by functional Magnetic Resonance Imaging (fMRI) during an N-Back task. Ethnicity, age, sex, subjective SES, and family structure were the study covariates. For data analysis, we used linear regression models. Results. In White but not Black adolescents, parental education was associated with higher left lateral OFC activity during the N-Back task. In the pooled sample, we found a significant interaction between race and parental education on the outcome, suggesting that high parental education is associated with a larger increase in left OFC activity of White than Black adolescents. Conclusions. For American adolescents, race and SES jointly influence left lateral OFC activity correlated with cognition, memory, decision making, and learning. Given the central role of left lateral OFC activity in learning and memory, our finding calls for additional research on contextual factors that reduce the gain of SES for Black adolescents. Cognitive inequalities are not merely due to the additive effects of race and SES but also its multiplicative effects.

Keywords: population groups; socioeconomic factors; adolescents; brain development; fMRI; cognitive; N-Back; memory; learning; orbitofrontal cortex 


\section{Introduction}

Given that socioeconomic status (SES) indicators such as parental education [1] are closely associated with exposure to chronic stress [2] and social adversities, and given that stress and adversities jeopardize adolescents' brain development [3-6], it should be no surprise that there is a connection between SES indicators such as parental education and adolescents brain development [7-14]. Adolescents from low and high SES experience vastly different social and economic adversity levels, thus showing considerable brain function changes [15-17]. As a result of poor brain development, adolescents from low SES families become at risk of undesired cognitive, emotional, and behavioral outcomes such as poor school performance [18], depression [19], anxiety [20,21], antisocial behaviors [22], aggression [23], and sexual initiation [24-26], as well as the use of tobacco [27,28], alcohol [29,30], and other drugs [31].

The effects of SES and associated stress are not specific to a particular brain region, but their effects are shown for multiple brain regions, including the amygdala [15,32,33], hippocampus [34-36], as well as the cerebral cortex. However, due to the scarcity of research on SES's effects on brain regions, our understanding of brain regions that are affected by SES is inconsistent.

Among various brain regions and structures that carry the effect of SES is the Orbitofrontal Cortex (OFC), a cortical structure with major implications in cognition, memory, decision making, and learning. As such, OFC activity correlates with such cognitive brain abilities [37-40]. The OFC has been shown to be affected by stress and SES [41]. Individuals with low performance or shrinkage of the OFC may show poor learning ability and memory. Several studies have shown that race, SES, and stress impact OFC. Altered OFC structure and function are also shown to be a part of dementia [42], Alzheimer's disease [43,44], psychosis [45,46], post-traumatic stress disorder (PTSD) [47,48], depression [49-51], and drug use [52-54].

Most of the existing literature on the link between SES and adolescents' brain development has focused on various aspects of emotion regulation rather than domains of memory and cognition $[15,32,33,55]$. Similarly, most of the existing research on the effects of stress and SES is limited to amygdala structure and function $[15,32,33,55]$. For example, Javanbakht et al. have documented the effects of household SES and childhood stress on amygdala response to threatening stimuli $[15,32,33]$. However, less is known on the effect of SES and environment on the OFC [41,56].

Accurate knowledge regarding the nature of the undesired effect of low SES on brain development and function will help us better understand why low SES adolescents report worse developmental outcomes [57], school performance [57], mental health [58], emotion regulation [59,60], aggression [61], and substance use [58,62]. Such research-based knowledge on how SES operates as a social determinant of adolescents' brain development and function is core for breaking the vicious cycle between low family SES and poor child developmental outcomes across multiple emotional and behavioral domains.

Theoretically, the scarcity hypothesis explains why and how SES deteriorates healthy adolescents' brain development. According to this theoretical framework, low SES reflects the scarcity of resources that are essential for adolescents' brain development. In this view, food and home insecurity increase the risk for poor child development. As such, poor access to resources that are buffers against poor developmental outcomes is one of the many mechanisms that may explain the link between low SES and poor brain development [63]. Low family SES is also a proxy of poor parenting [64-68] and high parental risk behaviors $[69,70]$ that can put child brain development in jeopardy [71]. Secondary to these cumulative risks, adolescents from low SES families remain at high level of risk of psychopathologies [72-74], problem behaviors [75-81], and poor school performance [82-84].

Multiple reasons suggest the association between SES and race/ethnicity are complex and interactive. First, race/ethnicity and SES have a major overlapping distribution [85,86]. Low SES may even mediate (explain) the racial and ethnic disparities in adolescents' brain 
development [87]. In addition, SES may have differential impacts on adolescent brain development across diverse racial and ethnic groups [55]. One study suggested that family income has stronger effects on brain function for the most disadvantaged than the least disadvantaged groups in the society [55].

In contrast, according to the Minorities' Diminished Returns (MDRs) framework [88], racial and ethnic minorities show weaker associations between SES and outcomes [89,90]. In several studies in children, youth, adults, and older adults, family SES shows weaker effects for Blacks than Whites [87,91-95]. As a result of MDRs, while White youth from high SES backgrounds show the lowest level of risk, Black adolescents remain at high risk regardless of SES, a pattern similarly relevant to behavioral, developmental, and health outcomes [89,96]. These patterns are shown across emotional, behavioral, and cognitive domains such as high-risk behaviors [96], aggression [96] and tobacco use [97], anxiety [98], depression [99], poor health [87], chronic disease, obesity, poor school attachment, impulsivity, and poor school performance [83]. These indicate a novel mechanism of health inequalities which is systematically overlooked by researchers and policymakers and suggest health disparities are not just due to lack of access to SES but also societal inequalities that slow, hinder, and block the process of translation of an SES resource (e.g., parental education) to an outcome (e.g., youth brain development).

Aims

To understand the social patterning of American adolescents' brain development, we conducted this study with two aims: First, to study the effect of SES on left lateral OFC activity measured during an N-Back task. Using the Adolescent Brain Cognitive Development (ABCD) data, which are from the state-of-the-art study of adolescents' brain development [100-113], we hypothesized that high parental education, as a major SES indicator, would be associated with a higher left lateral OFC activity. We also hypothesized that when comparing White and Black adolescents, the positive association between SES (parental education) and the left lateral OFC activity measured during an N-Back task would be weaker in Black than White adolescents, in line with the MDRs framework $[88,96]$.

\section{Methods}

\subsection{Study Design}

We conducted a secondary analysis of the data from the Adolescent Brain Cognitive Development (ABCD) study $[102,103,109,114,115]$. This study applied a cross-sectional design and only used wave one of the ABCD data [100-113]. ABCD study is the largest brain imaging studies of adolescents in the US [109,116].

\subsection{Sample and Sampling}

Participants were recruited from school systems in 21 study sites, which were distributed across multiple states. The recruitment was limited to 9-10-year-old children. To increase the generalizability of the sample, schools were selected based on their distribution of race, ethnicity, SES, sex, and urbanicity. For more information, please consult a fully detailed description of the ABCD sample and sampling [112]. The current analysis was performed in 4290 9-10-year-old White or Black adolescents. Participants were included in this analysis if they had complete data on all study variables.

\subsection{Variables}

The study variables included demographic factors (age and sex), SES indicators (parental educational attainment, subjective SES), and left lateral OFC activity (mean beta weight for N-Back run 12 back conditions in APARC ROI left lateral orbitofrontal: tfmri_nback_r1_349). Left lateral OFC activity was measured using a task-based functional MRI measure during N-Back. Details of the procedures for harmonization of the fMRIs and imaging are explained elsewhere [102]. 


\subsubsection{Outcome}

The outcome was left lateral OFC activity measured as mean beta weight for N-Back run 12 back conditions in APARC ROI left lateral orbitofrontal: tfmri_nback_r1_349. We selected the left lateral OFC because it is shown to be impacted by poverty, trauma, and adversity [56,117-120].

\subsubsection{Moderator}

Race. Race was self-identified and treated as a dichotomous variable: Black $=1$, White $=0$ (reference group).

\subsubsection{Independent Variables}

Parental Educational Attainment. Participants were asked, "What is the highest grade or level of school you have completed or the highest degree you have received?" Responses ranged from 0 (Never attended/Kindergarten) to 21 (doctoral degree). This variable ranged from 1 to 21 .

Financial Status. This study measured financial status using the following seven items: "In the past 12 months, has there been a time when you and your immediate family experienced any of the following:" (1) "Needed food but couldn't afford to buy it or couldn't afford to go out to get it?", (2) "Were without telephone service because you could not afford it?" (3)" Didn't pay the full amount of the rent or mortgage because you could not afford it?", (4) "Were evicted from your home for not paying the rent or mortgage?", (5)"Had services turned off by the gas or electric company, or the oil company wouldn't deliver oil because payments were not made?", (6) "Had someone who needed to see a doctor or go to the hospital but didn't go because you could not afford it?" and (7) "Had someone who needed a dentist but couldn't go because you could not afford it?" [121-127]. Subjective financial status predicts health beyond objective SES [121,123,124,128-130].

\subsubsection{Confounders}

Age, sex, ethnicity, and marital status were the confounders. Parents reported adolescents' age. Age was calculated as the distance of the date of birth to the date of enrollment to the study. Age was measured in years. Sex was a dichotomous variable with males as 1 and females as 0 . Parental marital status was a dichotomous variable: Married $=1$, unmarried $=0$ (reference category). Parents reported their ethnicity. Participants' ethnicity was coded as 1 for Hispanic and 0 for non-Hispanic.

\subsection{Data Analysis}

We used Statistical Package for the Social Sciences (SPSS) for our data analysis. Frequency $(\%)$ and mean (standard deviation [SD]) were described overall and by race. We used Pearson Chi-square and independent samples $t$-test to compare Blacks and White adolescents. To perform our multivariable analyses, we ran four multivariable linear regressions. The independent variable was the SES indicator (parental education). The outcome was left lateral OFC activity during the N-Back task. All these models controlled for age, sex, financial difficulties, and marital status. Model 1 was performed in Whites. Model 2 was performed in Blacks. Model 3 was performed in the pooled sample without the interaction term. Model 4 was performed in the pooled sample with the interaction term. We reported unstandardized regression coefficients (b), standard errors (SE), $95 \%$ confidence interval (CI), $t$ value, and their $p$-values. Any $p$-value of less than 0.05 was considered statistically significant. We did not adjust for multiple comparisons because, despite extensive fMRI data in the ABCD study, other brain regions' available data were not analyzed. As we only analyzed data on lateral OFC function, we kept our $p$-value threshold as 0.05 .

\subsection{Ethics}

The study protocol of the $A B C D$ study received approval from the Institutional Review Board (IRB) of the University of California, San Diego. Adolescent participants gave assent. 
Adult participants (parents) signed informed consent [116]. As our analysis applied fully de-identified data, our study was exempt from a full IRB review by our institution.

\section{Results}

\subsection{Descriptives}

Table 1 shows the descriptive characteristics of the 4290 8-11 years old participating adolescents who were either White $(n=3436 ; 80.1 \%)$ or Blacks $(n=854 ; 19.9 \%)$. This table also describes the descriptive characteristics of the pooled sample overall and by race. Black and White adolescents differed in family SES but not age or gender or the left lateral OFC activity. Compared to White adolescents, Black adolescents were less likely to be from married families, had lower parental education, and had more financial stress.

Table 1. Descriptive data overall and by race $(n=4290)$.

\begin{tabular}{|c|c|c|c|c|c|c|}
\hline & \multicolumn{2}{|c|}{$\begin{array}{c}\text { All } \\
(n=4290)\end{array}$} & \multicolumn{2}{|c|}{$\begin{array}{c}\text { Whites } \\
(n=3436)\end{array}$} & \multicolumn{2}{|c|}{$\begin{array}{c}\text { Blacks } \\
(n=854)\end{array}$} \\
\hline & $n$ & $\%$ & $n$ & $\%$ & $n$ & $\%$ \\
\hline \multicolumn{7}{|l|}{ Ethnicity *a } \\
\hline Non-Hispanic & 3582 & 83.5 & 2811 & 81.8 & 771 & 90.3 \\
\hline $\begin{array}{l}\text { Hispanic } \\
\text { Sex } * a\end{array}$ & 708 & 16.5 & 625 & 18.2 & 83 & 9.7 \\
\hline Male & 1985 & 46.3 & 1581 & 46 & 404 & 47.3 \\
\hline Female & 2305 & 53.7 & 1855 & 54 & 450 & 52.7 \\
\hline \multicolumn{7}{|l|}{ Family Structure * a } \\
\hline Not-Married & 1258 & 29.3 & 707 & 20.6 & 551 & 64.5 \\
\hline \multirow{2}{*}{ Married } & 3032 & 70.7 & 2729 & 79.4 & 303 & 35.5 \\
\hline & Mean & SD & Mean & SD & Mean & SD \\
\hline Age $($ Year $) * b$ & 9.49 & 0.51 & 9.50 & 0.50 & 9.49 & 0.51 \\
\hline Parental Education *b & 0.94 & 0.15 & 0.96 & 0.12 & 0.87 & 0.20 \\
\hline Subjective Financial Status $* \mathrm{~b}$ & 16.89 & 2.48 & 17.22 & 2.36 & 15.56 & 2.53 \\
\hline the left lateral OFC Function *b & 0.50 & 0.86 & 0.46 & 0.69 & 0.66 & 1.34 \\
\hline
\end{tabular}

${ }^{*} p<0.05$ for a comparison of Whites and Blacks. ${ }^{\mathrm{a}}$ Chi-Square test, ${ }^{\mathrm{b}}$ independent samples $t$-test; OFC: Orbito-Frontal Cortex.

\subsection{Race-Specific Associations}

Table 2 reports the results of two race-specific models for the N-Back task results in White and Black children. Model 1 was performed in White adolescents, and Model 2 was performed in Black adolescents. We found that parental education was associated with left lateral OFC function during the N-Back task in White but not Black adolescents.

Table 2. Linear regressions by racial group.

\begin{tabular}{|c|c|c|c|c|c|c|c|c|c|c|c|c|c|c|}
\hline \multirow[b]{3}{*}{ Ethnicity } & \multicolumn{7}{|c|}{$\begin{array}{l}\text { Model } 1 \\
\text { White }\end{array}$} & \multicolumn{7}{|c|}{$\begin{array}{c}\text { Model } 2 \\
\text { Black }\end{array}$} \\
\hline & \multirow{2}{*}{$\begin{array}{c}\mathbf{b} \\
0.04\end{array}$} & \multicolumn{2}{|l|}{ SE } & \multicolumn{2}{|c|}{$95 \%$ CI } & \multirow{2}{*}{$\frac{\mathbf{t}}{1.11}$} & \multirow{2}{*}{$\begin{array}{c}p \\
0.266\end{array}$} & \multirow{2}{*}{$\frac{\mathbf{b}}{-0.06}$} & \multicolumn{2}{|l|}{ SE } & \multicolumn{2}{|c|}{$95 \%$ CI } & \multirow{2}{*}{$\frac{\mathbf{t}}{-0.37}$} & \multirow{2}{*}{$\frac{p}{0.708}$} \\
\hline & & 0.03 & 0.02 & -0.03 & 0.10 & & & & 0.16 & -0.01 & -0.36 & 0.25 & & \\
\hline Sex (Male) & 0.06 & 0.02 & 0.04 & 0.01 & 0.11 & 2.52 & 0.012 & -0.02 & 0.09 & -0.01 & -0.20 & 0.17 & -0.17 & 0.864 \\
\hline Age & -0.09 & 0.02 & -0.06 & -0.13 & -0.04 & -3.73 & $<0.001$ & -0.10 & 0.09 & -0.04 & -0.27 & 0.08 & -1.06 & 0.291 \\
\hline Married & -0.01 & 0.03 & -0.01 & -0.07 & 0.05 & -0.43 & 0.666 & -0.14 & 0.10 & -0.05 & -0.34 & 0.07 & -1.32 & 0.187 \\
\hline $\begin{array}{c}\text { Subjective } \\
\text { Financial Status }\end{array}$ & -0.06 & 0.10 & -0.01 & -0.25 & 0.14 & -0.59 & 0.557 & 0.04 & 0.23 & 0.01 & -0.42 & 0.49 & 0.17 & 0.867 \\
\hline Parental education & 0.01 & 0.01 & 0.04 & 0.00 & 0.02 & 2.22 & 0.026 & -0.03 & 0.02 & -0.06 & -0.07 & 0.01 & -1.62 & 0.105 \\
\hline Constant & 1.10 & 0.25 & & 0.61 & 1.59 & 4.38 & $<0.001$ & 2.08 & 0.91 & & 0.29 & 3.87 & 2.28 & 0.023 \\
\hline
\end{tabular}

\subsection{Overall Associations}

Table 3 reports the results of regressions overall. In Model 3, parental education was not correlated with left lateral OFC activity during the N-Back task. In Model 4, a significant interaction was found, suggesting that parental education and left lateral 
OFC activity during the N-Back task show a stronger positive association in White than Black adolescents.

Table 3. Linear regressions overall.

\begin{tabular}{|c|c|c|c|c|c|c|c|c|c|c|c|c|c|c|}
\hline & \multicolumn{7}{|c|}{$\begin{array}{c}\text { Model } 3 \\
\text { Main Effects }\end{array}$} & \multicolumn{7}{|c|}{$\begin{array}{c}\text { Model } 4 \\
\text { Main Effects + Interaction }\end{array}$} \\
\hline & B & SE & & $95 \% \mathrm{CI}$ & $\mathbf{t}$ & p & $p$ & b & SE & & $95 \% \mathrm{CI}$ & $\mathbf{t}$ & p & $p$ \\
\hline Race (Blacks) & 0.04 & 0.03 & 0.02 & -0.03 & 0.10 & 1.11 & 0.266 & 0.04 & 0.03 & 0.02 & -0.03 & 0.10 & 1.11 & 0.266 \\
\hline Ethnicity & -0.01 & 0.04 & 0.00 & -0.08 & 0.07 & -0.16 & 0.875 & 0.02 & 0.04 & 0.01 & -0.05 & 0.09 & 0.51 & 0.613 \\
\hline Sex (Male) & 0.04 & 0.03 & 0.02 & -0.01 & 0.09 & 1.63 & 0.103 & 0.04 & 0.03 & 0.03 & -0.01 & 0.10 & 1.68 & 0.093 \\
\hline Age & -0.09 & 0.03 & -0.05 & -0.14 & -0.04 & -3.54 & $<0.001$ & -0.09 & 0.03 & -0.05 & -0.14 & -0.04 & -3.45 & 0.001 \\
\hline Married & -0.05 & 0.03 & -0.03 & -0.12 & 0.01 & -1.64 & 0.102 & -0.05 & 0.03 & -0.02 & -0.11 & 0.02 & -1.40 & 0.162 \\
\hline Subjective Financial Status & -0.01 & 0.10 & 0.00 & -0.19 & 0.18 & -0.08 & 0.933 & -0.04 & 0.12 & -0.01 & -0.29 & 0.20 & -0.35 & 0.724 \\
\hline Parental education & 0.00 & 0.01 & 0.00 & -0.01 & 0.01 & 0.05 & 0.960 & 0.01 & 0.01 & 0.04 & 0.00 & 0.03 & 1.83 & 0.067 \\
\hline $\begin{array}{c}\text { Race } \times \text { Subjective } \\
\text { Financial Status }\end{array}$ & & & & & & & & 0.07 & 0.19 & 0.03 & -0.31 & 0.44 & 0.35 & 0.729 \\
\hline Race $\times$ Parental education & & & & & & & & -0.05 & 0.01 & -0.37 & -0.08 & -0.02 & -3.70 & $<0.001$ \\
\hline Constant & 1.36 & 0.27 & & 0.82 & 1.90 & 4.94 & $<0.001$ & 1.14 & 0.29 & & 0.58 & 1.71 & 3.99 & $<0.001$ \\
\hline
\end{tabular}

\section{Discussion}

Parental education was associated with White but not Black OFC activity during the N-Back task. We also found an interaction confirming the same results.

Several studies have explored separate, additive, or multiplicative effects of race and SES on brain function. Most of these studies, however, have investigated separate effects of SES and race. There are only a few, if any, on the multiplicative effects of SES and race on brain development $[63,131]$. In addition, across SES indicators, the most common indicator has been poverty status, followed by income [15,32,33]. Parental education attainment has not been commonly investigated. Regarding brain regions and structures, most research has studied the amygdala and limbic system [15,32,33], rather than the left lateral OFC. Finally, many scholars do not wish to explore racial differences in brain imaging and function to avoid conflict. This is an overly politicized area of research with significant policy implications. Political correctness has reduced the likelihood of researchers to study how race and SES interact on brain development.

A study explored the associations between family SES (childhood poverty) and functional connectivity between the following brain regions: The hippocampus, amygdala, superior frontal cortex, lingual gyrus, posterior cingulate, and putamen. The study showed that childhood poverty predicts a lower level of connectivity between these regions, and these reduced brain connectivities mediate the effect of childhood poverty on adolescents' depression [131]. In a series of fMRI publications, a group of researchers, including Javanbakht, established a link between low family SES and functional connectivities between PFC, amygdala, and other brain regions [15,32,33]. These altered connectivities may be why low SES is associated with hyperactivation of the reward network and hypoactivation of the executive network [63]. Thus, the effects of SES and poverty go beyond a particular brain structure and can be seen for connectivity between several brain structures that regulate memory, executive functioning, cognition, and emotion [132]. It is still unknown to what degree the effects of poverty on brain functions are mediated or moderated by positive parenting [133].

Our study findings suggested that Black adolescents face double jeopardy. While race is associated with some altered function of the hippocampus, low SES is also another risk factor for them. There is, however, racial variations in the effects of SES on hippocampus activation during an N-Back task. For Blacks, low SES may come with a higher impact on their hippocampus. The more salient effects of low SES on the hippocampus of Black than White adolescents may be due to the cumulative effects of adversities in the life of racial and ethnic minorities and underserved populations. Racial discrimination and race-related stress may also have some role. Racial discrimination has been shown to impact a wide array of brain regions such as the PFC, anterior insula, putamen, amygdala, caudate, hippocampus, anterior cingulate, and medial frontal gyrus [134]. 
However, our study is not in support of most previous epidemiological studies that have explored racial differences in the health effects of SES. Many studies have shown more significant effects of SES on outcomes for White than Black adolescents [87]. For example, family SES has shown larger effects on ADHD [90], anxiety [98], aggression [96], tobacco dependence [96], school bonding [135], school performance [83], and overall health [136] for White than Black adolescents. This epidemiological research introduces family SES as a more salient determinant of impulsivity for White than Black adolescents [137]. Thus, we observe poor mental health, physical health, and risk behaviors in high SES Black adolescents $[89,90]$. These patterns are described as MDRs and hold across age groups, SES indicators, and health outcomes [88].

Differential effects of SES for Black and White families contribute to the transgenerational transmission of inequalities $[89,96,136]$. Differential effects of SES mean that equal SES generates unequal outcomes for the next generation of adolescents, which means the reproduction of inequalities across generations for Blacks. However, most of the previous studies on MDRs have relied on self-reported outcomes and family SES. Thus, the evidence lacked biological and brain imaging studies that test differential effects of SES on adolescents' brain function. This paper extended the existing literature by testing such patterns on brain development.

\subsection{Cautionary Note}

In this study, we conceptualized and theorized race as a social factor (a proxy of poverty and SES) on how the brain is affected by low or high SES (parental education). Our approach is different from studies that explore racial variation in brain function or structure as such differences are innate and non-modifiable. We believe that the observed racial differences are more to do with living conditions than genetic predisposition. In this investigation, we studied the former rather than the latter.

\subsection{Future Research Directions}

There is a need for identification and elimination of structural causes of MDRs in Black adolescents and families. Some of the suspects that require future research include racial segregation, school segregation, stress, or exposure to toxins such as air pollutants and lead. These environmental factors may have a role in reducing the health effects of SES for Black families. Labor market discrimination, job availability, discrimination, and segregation may play a role in this regard. There is a need to compare other racial and ethnic groups such as Asian Americans, Native Americans, Hispanics, and immigrants for the effects of SES on the left lateral OFC. Research should also go beyond the left lateral OFC and include other structures that have implications for emotion regulation, memory, cognition, learning, and behaviors.

\subsection{Limitations}

To list the study limitations, one is the cross-sectional design. Due to the design issue, findings should not and cannot be interpreted as causation but rather an association between race, SES, and brain development. SES and brain development have bidirectional associations; thus, future research should also address reverse causation. Second, we only had two SES indicators, namely parental education and financial difficulties. This is particularly important because neighborhood and contextual factors could be why parental education does not generate the same outcome for Black and White families. Third, N-Back provides insight regarding both emotion regulation as well as working memory. This study, however, exclusively focused on a brain mechanism that is involved in working memory.

\section{Conclusions}

In summary, high parental education is correlated with the left lateral OFC activation during the N-Back task in a national sample of White but not Black American adolescents. This observation is also supported by an interaction in the pooled sample suggesting that 
the magnitude of parental education's effect on the left lateral OFC function during the $\mathrm{N}$-Back task is less pronounced for Black than White adolescents. More research is needed on the complexities between the effects of race, SES, and social environment on adolescents' brain development, including but not limited to the left lateral OFC function and other structures with the implication in decision making, learning, and memory.

Author Contributions: S.A.: Conceptual model, data analysis, write up, revision, approval of the paper. S.B., M.S., M.B., C.H.C.: Conceptual model, revision, approval of the paper. All authors have read and agreed to the published version of the manuscript.

Funding: Assari is supported by the NIH grants CA201415-02, 5S21MD000103, 54MD008149, R25 MD007610, 2U54MD007598, 4P60MD006923, and U54 TR001627. Multiple NIH funds ABCD study under awards.

Institutional Review Board Statement: The study protocol of the ABCD study received approval from the Institutional Re-view Board (IRB) of the University of California, San Diego.

Informed Consent Statement: Informed consent was obtained from all subjects involved in the study.

Data Availability Statement: Data are available at The National Institute of Mental Health Data Archive (NDA) accessible at https:/ / nda.nih.gov/abcd (accessed on 22 March 2021).

Acknowledgments: Data used in the preparation of this article were obtained from the Adolescent Brain Cognitive Development (ABCD) Study. This is a multisite, longitudinal study designed to recruit more than 10,000 children aged 9-10 years and follow them over 10 years into early adulthood. The ABCD Study is supported by the National Institutes of Health and additional federal partners under award numbers U01DA041022, U01DA041028, U01DA041048, U01DA041089, U01DA041106, U01DA041117, U01DA041120, U01DA041134，U01DA041148，U01DA041156，U01DA041174, U24DA041123, and U24DA041147. A full list of supporters is available at https:/ / abcdstudy.org/nihcollaborators (accessed on 1 March 2021). A listing of participating sites and a complete listing of the study investigators can be found at https: / / abcdstudy.org/principal-investigators.html (accessed on 1 March 2021). ABCD consortium investigators designed and implemented the study and/or provided data but did not necessarily participate in analysis or writing of this report. This manuscript reflects the views of the authors and may not reflect the opinions or views of the National Institutes of Health (NIH) or ABCD consortium investigators. The ABCD data repository grows and changes over time. The ABCD data used in this report came from [NIMH Data Archive Digital Object Identifier (http:/ / dx.doi.org/10.15154/1504041) (accessed on 1 March 2021)]. This manuscript reflects the views of the authors and may not reflect the opinions or views of the NIH or ABCD consortium investigators. The author wishes to thank Gavin Wells for his edits to this paper.

Conflicts of Interest: The authors declare no conflict of interest.

\section{References}

1. Oshri, A.; Hallowell, E.; Liu, S.; MacKillop, J.; Galvan, A.; Kogan, S.M.; Sweet, L.H. Socioeconomic hardship and delayed reward discounting: Associations with working memory and emotional reactivity. Dev. Cogn. Neurosci. 2019, 37, 100642. [CrossRef]

2. Lantz, P.M.; House, J.S.; Mero, R.P.; Williams, D.R. Stress, life events, and socioeconomic disparities in health: Results from the Americans' Changing Lives Study. J. Health Soc. Behav. 2005, 46, 274-288. [CrossRef] [PubMed]

3. Herzog, J.I.; Schmahl, C. Adverse Childhood Experiences and the Consequences on Neurobiological, Psychosocial, and Somatic Conditions Across the Lifespan. Front. Psychiatry 2018, 9, 420. [CrossRef] [PubMed]

4. McCreary, J.K.; Truica, L.S.; Friesen, B.; Yao, Y.; Olson, D.M.; Kovalchuk, I.; Cross, A.R.; Metz, G.A. Altered brain morphology and functional connectivity reflect a vulnerable affective state after cumulative multigenerational stress in rats. Neuroscience 2016, 330, 79-89. [CrossRef]

5. Pagliaccio, D.; Luby, J.L.; Bogdan, R.; Agrawal, A.; Gaffrey, M.S.; Belden, A.C.; Botteron, K.N.; Harms, M.P.; Barch, D.M. Amygdala functional connectivity, HPA axis genetic variation, and life stress in children and relations to anxiety and emotion regulation. J. Abnorm. Psychol. 2015, 124, 817-833. [CrossRef] [PubMed]

6. Pegg, S.; Ethridge, P.; Shields, G.S.; Slavich, G.M.; Weinberg, A.; Kujawa, A. Blunted Social Reward Responsiveness Moderates the Effect of Lifetime Social Stress Exposure on Depressive Symptoms. Front. Behav. Neurosci. 2019, 13, 178. [CrossRef]

7. Hair, N.L.; Hanson, J.L.; Wolfe, B.L.; Pollak, S.D. Association of Child Poverty, Brain Development, and Academic Achievement. JAMA Pediatr. 2015, 169, 822-829. [CrossRef] [PubMed] 
8. Benavente-Fernandez, I.; Synnes, A.; Grunau, R.E.; Chau, V.; Ramraj, C.; Glass, T.; Cayam-Rand, D.; Siddiqi, A.; Miller, S.P. Association of Socioeconomic Status and Brain Injury with Neurodevelopmental Outcomes of Very Preterm Children. JAMA Netw. Open 2019, 2, e192914. [CrossRef] [PubMed]

9. Machlin, L.; McLaughlin, K.A.; Sheridan, M.A. Brain structure mediates the association between socioeconomic status and attention-deficit/hyperactivity disorder. Dev. Sci. 2019, e12844. [CrossRef]

10. Fotenos, A.F.; Mintun, M.A.; Snyder, A.Z.; Morris, J.C.; Buckner, R.L. Brain volume decline in aging: Evidence for a relation between socioeconomic status, preclinical Alzheimer disease, and reserve. Arch. Neurol. 2008, 65, 113-120. [CrossRef]

11. Lawson, G.M.; Camins, J.S.; Wisse, L.; Wu, J.; Duda, J.T.; Cook, P.A.; Gee, J.C.; Farah, M.J. Childhood socioeconomic status and childhood maltreatment: Distinct associations with brain structure. PLoS ONE 2017, 12, e0175690. [CrossRef] [PubMed]

12. Deuschle, M.; Hendlmeier, F.; Witt, S.; Rietschel, M.; Gilles, M.; Sanchez-Guijo, A.; Fananas, L.; Hentze, S.; Wudy, S.A.; Hellweg, R. Cortisol, cortisone, and BDNF in amniotic fluid in the second trimester of pregnancy: Effect of early life and current maternal stress and socioeconomic status. Dev. Psychopathol. 2018, 30, 971-980. [CrossRef] [PubMed]

13. Betancourt, L.M.; Avants, B.; Farah, M.J.; Brodsky, N.L.; Wu, J.; Ashtari, M.; Hurt, H. Effect of socioeconomic status (SES) disparity on neural development in female African-American infants at age 1 month. Dev. Sci. 2016, 19, 947-956. [CrossRef] [PubMed]

14. Raizada, R.D.; Kishiyama, M.M. Effects of socioeconomic status on brain development, and how cognitive neuroscience may contribute to levelling the playing field. Front. Hum. Neurosci. 2010, 4, 3. [CrossRef] [PubMed]

15. Javanbakht, A.; King, A.P.; Evans, G.W.; Swain, J.E.; Angstadt, M.; Phan, K.L.; Liberzon, I. Childhood Poverty Predicts Adult Amygdala and Frontal Activity and Connectivity in Response to Emotional Faces. Front. Behav. Neurosci. 2015, 9, 154. [CrossRef]

16. Masten, C.L.; Telzer, E.H.; Eisenberger, N.I. An FMRI investigation of attributing negative social treatment to racial discrimination. J. Cogn. Neurosci. 2011, 23, 1042-1051. [CrossRef]

17. Wu, X.; Zou, Q.; Hu, J.; Tang, W.; Mao, Y.; Gao, L.; Zhu, J.; Jin, Y.; Wu, X.; Lu, L.; et al. Intrinsic Functional Connectivity Patterns Predict Consciousness Level and Recovery Outcome in Acquired Brain Injury. J. Neurosci. 2015, 35, 12932-12946. [CrossRef]

18. Sirin, S.R. Socioeconomic status and academic achievement: A meta-analytic review of research. Rev. Educ. Res. 2005, 75, 417-453. [CrossRef]

19. Mendelson, T.; Kubzansky, L.D.; Datta, G.D.; Buka, S.L. Relation of female gender and low socioeconomic status to internalizing symptoms among adolescents: A case of double jeopardy? Soc. Sci. Med. 2008, 66, 1284-1296. [CrossRef]

20. Lee, J.O.; Herrenkohl, T.I.; Kosterman, R.; Small, C.M.; Hawkins, J.D. Educational inequalities in the co-occurrence of mental health and substance use problems, and its adult socio-economic consequences: A longitudinal study of young adults in a community sample. Public Health 2013, 127, 745-753. [CrossRef]

21. Silvernale, C.; Kuo, B.; Staller, K. Lower socioeconomic status is associated with an increased prevalence of comorbid anxiety and depression among patients with irritable bowel syndrome: Results from a multicenter cohort. Scand. J. Gastroenterol. 2019, 54, 1070-1074. [CrossRef] [PubMed]

22. Palma-Coca, O.; Hernandez-Serrato, M.I.; Villalobos-Hernandez, A.; Unikel-Santoncini, C.; Olaiz-Fernandez, G.; BojorquezChapela, I. Association of socioeconomic status, problem behaviors, and disordered eating in Mexican adolescents: Results of the Mexican National Health and Nutrition Survey 2006. J. Adolesc. Health 2011, 49, 400-406. [CrossRef]

23. Heshmat, R.; Qorbani, M.; Ghoreshi, B.; Djalalinia, S.; Tabatabaie, O.R.; Safiri, S.; Noroozi, M.; Motlagh, M.E.; Ahadi, Z.; Asayesh, H.; et al. Association of socioeconomic status with psychiatric problems and violent behaviours in a nationally representative sample of Iranian children and adolescents: The CASPIAN-IV study. BMJ Open 2016, 6, e011615. [CrossRef]

24. Stanger-Hall, K.F.; Hall, D.W. Abstinence-only education and teen pregnancy rates: Why we need comprehensive sex education in the US. PLoS ONE 2011, 6, e24658. [CrossRef]

25. Pilgrim, N.A.; Ahmed, S.; Gray, R.H.; Sekasanvu, J.; Lutalo, T.; Nalugoda, F.; Serwadda, D.; Wawer, M.J. Multiple sexual partnerships among female adolescents in rural Uganda: The effects of family structure and school attendance. Int. J. Adolesc. Med. Health 2015, 27, 319-328. [CrossRef]

26. Gutierrez, J.P.; Atienzo, E.E. Socioeconomic status, urbanicity and risk behaviors in Mexican youth: An analysis of three cross-sectional surveys. BMC Public Health 2011, 11, 900. [CrossRef]

27. Kaleta, D.; Usidame, B.; Dziankowska-Zaborszczyk, E.; Makowiec-Dabrowska, T. Socioeconomic Disparities in Age of Initiation and Ever Tobacco Smoking: Findings from Romania. Cent. Eur. J. Public Health 2015, 23, 299-305. [CrossRef] [PubMed]

28. Barreto, S.M.; de Figueiredo, R.C.; Giatti, L. Socioeconomic inequalities in youth smoking in Brazil. BMJ Open 2013 , 3, e003538. [CrossRef] [PubMed]

29. Moore, G.F.; Littlecott, H.J. School- and family-level socioeconomic status and health behaviors: Multilevel analysis of a national survey in wales, United Kingdom. J. Sch. Health 2015, 85, 267-275. [CrossRef] [PubMed]

30. Silveira, C.M.; Siu, E.R.; Anthony, J.C.; Saito, L.P.; de Andrade, A.G.; Kutschenko, A.; Viana, M.C.; Wang, Y.P.; Martins, S.S.; Andrade, L.H. Drinking patterns and alcohol use disorders in Sao Paulo, Brazil: The role of neighborhood social deprivation and socioeconomic status. PLoS ONE 2014, 9, e108355. [CrossRef] [PubMed]

31. Gerra, G.; Benedetti, E.; Resce, G.; Potente, R.; Cutilli, A.; Molinaro, S. Socioeconomic Status, Parental Education, School Connectedness and Individual Socio-Cultural Resources in Vulnerability for Drug Use among Students. Int. J. Environ. Res. Public Health 2020, 17, 1306. [CrossRef] [PubMed]

32. Evans, G.W.; Swain, J.E.; King, A.P.; Wang, X.; Javanbakht, A.; Ho, S.S.; Angstadt, M.; Phan, K.L.; Xie, H.; Liberzon, I. Childhood Cumulative Risk Exposure and Adult Amygdala Volume and Function. J. Neurosci. Res. 2016, 94, 535-543. [CrossRef] 
33. Javanbakht, A.; Kim, P.; Swain, J.E.; Evans, G.W.; Phan, K.L.; Liberzon, I. Sex-Specific Effects of Childhood Poverty on Neurocircuitry of Processing of Emotional Cues: A Neuroimaging Study. Behav. Sci. 2016, 6, 28. [CrossRef]

34. Wang, Y.; Zhang, L.; Kong, X.; Hong, Y.; Cheon, B.; Liu, J. Pathway to neural resilience: Self-esteem buffers against deleterious effects of poverty on the hippocampus. Hum. Brain Mapp. 2016, 37, 3757-3766. [CrossRef] [PubMed]

35. Baxendale, S.; Heaney, D. Socioeconomic status, cognition, and hippocampal sclerosis. Epilepsy Behav. 2011, 20, 64-67. [CrossRef] [PubMed]

36. Jenkins, L.M.; Chiang, J.J.; Vause, K.; Hoffer, L.; Alpert, K.; Parrish, T.B.; Wang, L.; Miller, G.E. Subcortical structural variations associated with low socioeconomic status in adolescents. Hum. Brain Mapp. 2020, 41, 162-171. [CrossRef]

37. Cox, S.M.; Andrade, A.; Johnsrude, I.S. Learning to like: A role for human orbitofrontal cortex in conditioned reward. J. Neurosci. 2005, 25, 2733-2740. [CrossRef]

38. Frey, S.; Petrides, M. Orbitofrontal cortex and memory formation. Neuron 2002, 36, 171-176. [CrossRef]

39. Oscar-Berman, M. The effects of dorsolateral-frontal and ventrolateral-orbitofrontal lesions on spatial discrimination learning and delayed response in two modalities. Neuropsychologia 1975, 13, 237-246. [CrossRef]

40. Premkumar, P.; Fannon, D.; Sapara, A.; Peters, E.R.; Anilkumar, A.P.; Simmons, A.; Kuipers, E.; Kumari, V. Orbitofrontal cortex, emotional decision-making and response to cognitive behavioural therapy for psychosis. Psychiatry Res. 2015, 231, 298-307. [CrossRef]

41. Goodwill, H.L.; Manzano-Nieves, G.; LaChance, P.; Teramoto, S.; Lin, S.; Lopez, C.; Stevenson, R.J.; Theyel, B.B.; Moore, C.I.; Connors, B.W.; et al. Early Life Stress Drives Sex-Selective Impairment in Reversal Learning by Affecting Parvalbumin Interneurons in Orbitofrontal Cortex of Mice. Cell Rep. 2018, 25, 2299-2307.e2294. [CrossRef]

42. Viskontas, I.V.; Possin, K.L.; Miller, B.L. Symptoms of frontotemporal dementia provide insights into orbitofrontal cortex function and social behavior. Ann. N. Y. Acad. Sci. 2007, 1121, 528-545. [CrossRef]

43. Hornberger, M.; Savage, S.; Hsieh, S.; Mioshi, E.; Piguet, O.; Hodges, J.R. Orbitofrontal dysfunction discriminates behavioral variant frontotemporal dementia from Alzheimer's disease. Dement. Geriatr. Cogn. Disord. 2010, 30, 547-552. [CrossRef]

44. Van Hoesen, G.W.; Parvizi, J.; Chu, C.C. Orbitofrontal cortex pathology in Alzheimer's disease. Cereb. Cortex 2000, 10, $243-251$. [CrossRef]

45. Bellani, M.; Cerruti, S.; Brambilla, P. Orbitofrontal cortex abnormalities in schizophrenia. Epidemiol. Psichiatr. Soc. 2010, 19, 23-25. [CrossRef]

46. Chakirova, G.; Welch, K.A.; Moorhead, T.W.; Stanfield, A.C.; Hall, J.; Skehel, P.; Brown, V.J.; Johnstone, E.C.; Owens, D.G.; Lawrie, S.M.; et al. Orbitofrontal morphology in people at high risk of developing schizophrenia. Eur. Psychiatry 2010, 25, 366-372. [CrossRef] [PubMed]

47. Jin, C.; Qi, R.; Yin, Y.; Hu, X.; Duan, L.; Xu, Q.; Zhang, Z.; Zhong, Y.; Feng, B.; Xiang, H.; et al. Abnormalities in whole-brain functional connectivity observed in treatment-naive post-traumatic stress disorder patients following an earthquake. Psychol. Med. 2014, 44, 1927-1936. [CrossRef] [PubMed]

48. Morey, R.A.; Haswell, C.C.; Hooper, S.R.; De Bellis, M.D. Amygdala, Hippocampus, and Ventral Medial Prefrontal Cortex Volumes Differ in Maltreated Youth with and without Chronic Posttraumatic Stress Disorder. Neuropsychopharmacology 2016, 41, 791-801. [CrossRef] [PubMed]

49. Cheng, W.; Rolls, E.T.; Qiu, J.; Xie, X.; Wei, D.; Huang, C.C.; Yang, A.C.; Tsai, S.J.; Li, Q.; Meng, J.; et al. Increased functional connectivity of the posterior cingulate cortex with the lateral orbitofrontal cortex in depression. Transl. Psychiatry 2018, 8, 90. [CrossRef] [PubMed]

50. Frodl, T.; Bokde, A.L.; Scheuerecker, J.; Lisiecka, D.; Schoepf, V.; Hampel, H.; Moller, H.J.; Bruckmann, H.; Wiesmann, M.; Meisenzahl, E. Functional connectivity bias of the orbitofrontal cortex in drug-free patients with major depression. Biol. Psychiatry 2010, 67, 161-167. [CrossRef] [PubMed]

51. Taylor, W.D.; Macfall, J.R.; Payne, M.E.; McQuoid, D.R.; Steffens, D.C.; Provenzale, J.M.; Krishnan, K.R. Orbitofrontal cortex volume in late life depression: Influence of hyperintense lesions and genetic polymorphisms. Psychol. Med. 2007, 37, 1763-1773. [CrossRef] [PubMed]

52. London, E.D.; Ernst, M.; Grant, S.; Bonson, K.; Weinstein, A. Orbitofrontal cortex and human drug abuse: Functional imaging. Cereb. Cortex 2000, 10, 334-342. [CrossRef]

53. Lopez-Larson, M.P.; Rogowska, J.; Yurgelun-Todd, D. Aberrant orbitofrontal connectivity in marijuana smoking adolescents. Dev. Cogn. Neurosci. 2015, 16, 54-62. [CrossRef]

54. Moorman, D.E. The role of the orbitofrontal cortex in alcohol use, abuse, and dependence. Prog. Neuropsychopharmacol. Biol. Psychiatry 2018, 87, 85-107. [CrossRef]

55. Noble, K.G.; Houston, S.M.; Brito, N.H.; Bartsch, H.; Kan, E.; Kuperman, J.M.; Akshoomoff, N.; Amaral, D.G.; Bloss, C.S.; Libiger, O. Family income, parental education and brain structure in children and adolescents. Nat. Neurosci. 2015, 18, 773. [CrossRef] [PubMed]

56. Holz, N.E.; Boecker, R.; Hohm, E.; Zohsel, K.; Buchmann, A.F.; Blomeyer, D.; Jennen-Steinmetz, C.; Baumeister, S.; Hohmann, S.; Wolf, I.; et al. The long-term impact of early life poverty on orbitofrontal cortex volume in adulthood: Results from a prospective study over 25 years. Neuropsychopharmacology 2015, 40, 996-1004. [CrossRef] [PubMed] 
57. Spera, C.; Wentzel, K.R.; Matto, H.C. Parental aspirations for their children's educational attainment: Relations to ethnicity, parental education, children's academic performance, and parental perceptions of school climate. J. Youth Adolesc. 2009, 38, 1140-1152. [CrossRef]

58. Goodman, E.; Slap, G.B.; Huang, B. The public health impact of socioeconomic status on adolescent depression and obesity. Am. J. Public Health 2003, 93, 1844-1850. [CrossRef] [PubMed]

59. Morris, A.S.; Silk, J.S.; Steinberg, L.; Myers, S.S.; Robinson, L.R. The role of the family context in the development of emotion regulation. Soc. Dev. 2007, 16, 361-388. [CrossRef]

60. Park, S.; Holloway, S.D. No parent left behind: Predicting parental involvement in adolescents' education within a sociodemographically diverse population. J. Educ. Res. 2013, 106, 105-119. [CrossRef]

61. Pabayo, R.; Molnar, B.E.; Kawachi, I. The role of neighborhood income inequality in adolescent aggression and violence. J. Adolesc. Health 2014, 55, 571-579. [CrossRef]

62. Wills, T.A.; McNamara, G.; Vaccaro, D. Parental education related to adolescent stress-coping and substance use: Development of a mediational model. Health Psychol. 1995, 14, 464. [CrossRef]

63. Yaple, Z.A.; Yu, R. Functional and Structural Brain Correlates of Socioeconomic Status. Cereb. Cortex 2019. [CrossRef] [PubMed]

64. Aubuchon-Endsley, N.L.; Kennedy, T.S.; Gilchrist, M.; Thomas, D.G.; Grant, S. Relationships among Socioeconomic Status, Dietary Intake, and Stress in Breastfeeding Women. J. Acad. Nutr. Diet. 2015, 115, 939-946 e931. [CrossRef] [PubMed]

65. Braren, S.H.; Perry, R.E.; Ursache, A.; Blair, C. Socioeconomic risk moderates the association between caregiver cortisol levels and infant cortisol reactivity to emotion induction at 24 months. Dev. Psychobiol 2019, 61, 573-591. [CrossRef]

66. Emmen, R.A.; Malda, M.; Mesman, J.; van Ijzendoorn, M.H.; Prevoo, M.J.; Yeniad, N. Socioeconomic status and parenting in ethnic minority families: Testing a minority family stress model. J. Fam. Psychol. 2013, 27, 896-904. [CrossRef] [PubMed]

67. Jackson, A.P.; Brooks-Gunn, J.; Huang, C.C.; Glassman, M. Single mothers in low-wage jobs: Financial strain, parenting, and preschoolers' outcomes. Child Dev. 2000, 71, 1409-1423. [CrossRef] [PubMed]

68. Liu, Y.; Lachman, M.E. Socioeconomic Status and Parenting Style from Childhood: Long-Term Effects on Cognitive Function in Middle and Later Adulthood. J. Gerontol. B Psychol. Sci. Soc. Sci. 2019, 74, e13-e24. [CrossRef]

69. Dutra, L.; Bureau, J.F.; Holmes, B.; Lyubchik, A.; Lyons-Ruth, K. Quality of early care and childhood trauma: A prospective study of developmental pathways to dissociation. J. Nerv. Ment. Dis. 2009, 197, 383-390. [CrossRef] [PubMed]

70. Ladebauche, P. Childhood trauma-When to suspect abuse. RN 1997, 60, 38-42; quiz 43. [PubMed]

71. Assari, S.; Bazargan, M. Unequal Associations between Educational Attainment and Occupational Stress across Racial and Ethnic Groups. Int. J. Environ. Res. Public Health 2019, 16, 3539. [CrossRef] [PubMed]

72. Chassin, L.; Presson, C.C.; Sherman, S.J.; Edwards, D.A. Parent educational attainment and adolescent cigarette smoking. J. Subst. Abus. 1992, 4, 219-234. [CrossRef]

73. Kocaoglu, B.; Moschonis, G.; Dimitriou, M.; Kolotourou, M.; Keskin, Y.; Sur, H.; Hayran, O.; Manios, Y. Parental educational level and cardiovascular disease risk factors in schoolchildren in large urban areas of Turkey: Directions for public health policy. BMC Public Health 2005, 5, 13. [CrossRef]

74. Padilla-Moledo, C.; Ruiz, J.R.; Castro-Pinero, J. Parental educational level and psychological positive health and health complaints in Spanish children and adolescents. Child Care Health Dev. 2016, 42, 534-543. [CrossRef] [PubMed]

75. Kauhanen, L.; Leino, J.; Lakka, H.M.; Lynch, J.W.; Kauhanen, J. Adverse childhood experiences and risk of binge drinking and drunkenness in middle-aged finnish men. Adv. Prev. Med. 2011, 2011, 478741. [CrossRef]

76. Choi, J.K.; Wang, D.; Jackson, A.P. Adverse experiences in early childhood and their longitudinal impact on later behavioral problems of children living in poverty. Child Abus. Negl. 2019, 98, 104181. [CrossRef]

77. Cuevas, A.G.; Chen, R.; Slopen, N.; Thurber, K.A.; Wilson, N.; Economos, C.; Williams, D.R. Assessing the Role of Health Behaviors, Socioeconomic Status, and Cumulative Stress for Racial/Ethnic Disparities in Obesity. Obesity 2020, 28, 161-170. [CrossRef]

78. Frankenberger, D.J.; Clements-Nolle, K.; Yang, W. The Association between Adverse Childhood Experiences and Alcohol Use during Pregnancy in a Representative Sample of Adult Women. Womens Health Issues 2015, 25, 688-695. [CrossRef] [PubMed]

79. Peyrot, W.J.; Lee, S.H.; Milaneschi, Y.; Abdellaoui, A.; Byrne, E.M.; Esko, T.; de Geus, E.J.; Hemani, G.; Hottenga, J.J.; Kloiber, S.; et al. The association between lower educational attainment and depression owing to shared genetic effects? Results in $\sim 25,000$ subjects. Mol. Psychiatry 2015, 20, 735-743. [CrossRef]

80. DeCuir, J.; Lovasi, G.S.; El-Sayed, A.; Lewis, C.F. The association between neighborhood socioeconomic disadvantage and high-risk injection behavior among people who inject drugs. Drug Alcohol Depend. 2018, 183, 184-191. [CrossRef] [PubMed]

81. Kuchibhatla, M.; Hunter, J.C.; Plassman, B.L.; Lutz, M.W.; Casanova, R.; Saldana, S.; Hayden, K.M. The association between neighborhood socioeconomic status, cardiovascular and cerebrovascular risk factors, and cognitive decline in the Health and Retirement Study (HRS). Aging Ment. Health 2019, 24, 1479-1486. [CrossRef]

82. Assari, S. Parental Educational Attainment and Academic Performance of American College Students; Blacks' Diminished Returns. J. Health Econ. Dev. 2019, 1, 21-31.

83. Assari, S.; Caldwell, C.H. Parental Educational Attainment Differentially Boosts School Performance of American Adolescents: Minorities' Diminished Returns. J. Fam. Reprod. Health 2019, 13, 7-13. [CrossRef]

84. Kiang, L.; Andrews, K.; Stein, G.L.; Supple, A.J.; Gonzalez, L.M. Socioeconomic stress and academic adjustment among Asian American adolescents: The protective role of family obligation. J. Youth Adolesc. 2013, 42, 837-847. [CrossRef] [PubMed] 
85. Williams, D.R. Race, socioeconomic status, and health the added effects of racism and discrimination. Ann. N. Y. Acad. Sci. 1999, 896, 173-188. [CrossRef]

86. Kaufman, J.S.; Cooper, R.S.; McGee, D.L. Socioeconomic status and health in blacks and whites: The problem of residual confounding and the resiliency of race. Epidemiology 1997, 8, 621-628. [CrossRef]

87. Assari, S. Parental Educational Attainment and Mental Well-Being of College Students; Diminished Returns of Blacks. Brain Sci. 2018, 8, 193. [CrossRef]

88. Assari, S. Unequal Gain of Equal Resources across Racial Groups. Int. J. Health Policy Manag. 2017, 7, 1-9. [CrossRef] [PubMed]

89. Assari, S.; Thomas, A.; Caldwell, C.H.; Mincy, R.B. Blacks' Diminished Health Return of Family Structure and Socioeconomic Status; 15 Years of Follow-up of a National Urban Sample of Youth. J. Urban Health 2018, 95, 21-35. [CrossRef]

90. Assari, S.; Caldwell, C.H. Family Income at Birth and Risk of Attention Deficit Hyperactivity Disorder at Age 15: Racial Differences. Children 2019, 6, 10. [CrossRef]

91. Assari, S.; Lankarani, M.M.; Caldwell, C.H. Does Discrimination Explain High Risk of Depression among High-Income African American Men? Behav. Sci. 2018, 8, 40. [CrossRef]

92. Fuller-Rowell, T.E.; Doan, S.N. The social costs of academic success across ethnic groups. Child. Dev. 2010, 81, 1696-1713. [CrossRef] [PubMed]

93. Fuller-Rowell, T.E.; Curtis, D.S.; Doan, S.N.; Coe, C.L. Racial disparities in the health benefits of educational attainment: A study of inflammatory trajectories among African American and white adults. Psychosom. Med. 2015, 77, 33-40. [CrossRef] [PubMed]

94. Hudson, D.L.; Bullard, K.M.; Neighbors, H.W.; Geronimus, A.T.; Yang, J.; Jackson, J.S. Are benefits conferred with greater socioeconomic position undermined by racial discrimination among African American men? J. Men's Health 2012, 9, 127-136. [CrossRef] [PubMed]

95. Hudson, D.L.; Neighbors, H.W.; Geronimus, A.T.; Jackson, J.S. The relationship between socioeconomic position and depression among a US nationally representative sample of African Americans. Soc. Psychiatry Psychiatr. Epidemiol. 2012, 47, 373-381. [CrossRef]

96. Assari, S.; Caldwell, C.H.; Bazargan, M. Association Between Parental Educational Attainment and Youth Outcomes and Role of Race/Ethnicity. JAMA Netw. Open 2019, 2, e1916018. [CrossRef] [PubMed]

97. Assari, S.; Mistry, R. Educational Attainment and Smoking Status in a National Sample of American Adults; Evidence for the Blacks' Diminished Return. Int. J. Environ. Res. Public Health 2018, 15, 763. [CrossRef]

98. Assari, S.; Caldwell, C.H.; Zimmerman, M.A. Family Structure and Subsequent Anxiety Symptoms; Minorities' Diminished Return. Brain Sci. 2018, 8, 97. [CrossRef]

99. Assari, S.; Caldwell, C.H. High Risk of Depression in High-Income African American Boys. J. Racial Ethn. Health Disparities 2018, 5, 808-819. [CrossRef]

100. Asaad, S.K.; Bjarkam, C.R. The Aalborg Bolt-Connected Drain (ABCD) study: A prospective comparison of tunnelled and bolt-connected external ventricular drains. Acta Neurochir. 2019, 161, 33-39. [CrossRef] [PubMed]

101. Bjork, J.M.; Straub, L.K.; Provost, R.G.; Neale, M.C. The ABCD study of neurodevelopment: Identifying neurocircuit targets for prevention and treatment of adolescent substance abuse. Curr. Treat. Options Psychiatry 2017, 4, 196-209. [CrossRef]

102. Casey, B.J.; Cannonier, T.; Conley, M.I.; Cohen, A.O.; Barch, D.M.; Heitzeg, M.M.; Soules, M.E.; Teslovich, T.; Dellarco, D.V.; Garavan, H.; et al. The Adolescent Brain Cognitive Development (ABCD) study: Imaging acquisition across 21 sites. Dev. Cogn. Neurosci. 2018, 32, 43-54. [CrossRef]

103. Lisdahl, K.M.; Sher, K.J.; Conway, K.P.; Gonzalez, R.; Feldstein Ewing, S.W.; Nixon, S.J.; Tapert, S.; Bartsch, H.; Goldstein, R.Z.; Heitzeg, M. Adolescent brain cognitive development (ABCD) study: Overview of substance use assessment methods. Dev. Cogn. Neurosci. 2018, 32, 80-96. [CrossRef] [PubMed]

104. Feldstein Ewing, S.W.; Chang, L.; Cottler, L.B.; Tapert, S.F.; Dowling, G.J.; Brown, S.A. Approaching Retention within the ABCD Study. Dev. Cogn. Neurosci. 2018, 32, 130-137. [CrossRef] [PubMed]

105. Michelini, G.; Barch, D.M.; Tian, Y.; Watson, D.; Klein, D.N.; Kotov, R. Delineating and validating higher-order dimensions of psychopathology in the Adolescent Brain Cognitive Development (ABCD) study. Transl. Psychiatry 2019, 9, 261. [CrossRef] [PubMed]

106. Beauchaine, T.P. Editorial: Family History of Depression and Child Striatal Volumes in the ABCD Study: Promise and Perils of Neuroimaging Research with Large Samples. J. Am. Acad. Child. Adolesc. Psychiatry 2020. [CrossRef]

107. Marek, S.; Tervo-Clemmens, B.; Nielsen, A.N.; Wheelock, M.D.; Miller, R.L.; Laumann, T.O.; Earl, E.; Foran, W.W.; Cordova, M.; Doyle, O.; et al. Identifying reproducible individual differences in childhood functional brain networks: An ABCD study. Dev. Cogn. Neurosci. 2019, 40, 100706. [CrossRef]

108. Feldstein Ewing, S.W.; Bjork, J.M.; Luciana, M. Implications of the ABCD study for developmental neuroscience. Dev. Cogn. Neurosci. 2018, 32, 161-164. [CrossRef]

109. Alcohol Research: Current Reviews Editorial, S. NIH's Adolescent Brain Cognitive Development (ABCD) Study. Alcohol Res. 2018, 39, 97.

110. Hoffman, E.A.; Howlett, K.D.; Breslin, F.; Dowling, G.J. Outreach and innovation: Communication strategies for the ABCD Study. Dev. Cogn. Neurosci. 2018, 32, 138-142. [CrossRef]

111. Rozzell, K.; Moon, D.Y.; Klimek, P.; Brown, T.; Blashill, A.J. Prevalence of Eating Disorders among US Children Aged 9 to 10 Years: Data from the Adolescent Brain Cognitive Development (ABCD) Study. JAMA Pediatr. 2019, 173, 100-101. [CrossRef] 
112. Garavan, H.; Bartsch, H.; Conway, K.; Decastro, A.; Goldstein, R.Z.; Heeringa, S.; Jernigan, T.; Potter, A.; Thompson, W.; Zahs, D. Recruiting the ABCD sample: Design considerations and procedures. Dev. Cogn. Neurosci. 2018, 32, 16-22. [CrossRef] [PubMed]

113. Hoffman, E.A.; Clark, D.B.; Orendain, N.; Hudziak, J.; Squeglia, L.M.; Dowling, G.J. Stress exposures, neurodevelopment and health measures in the ABCD study. Neurobiol. Stress 2019, 10, 100157. [CrossRef] [PubMed]

114. Karcher, N.R.; O’Brien, K.J.; Kandala, S.; Barch, D.M. Resting-State Functional Connectivity and Psychotic-like Experiences in Childhood: Results from the Adolescent Brain Cognitive Development Study. Biol. Psychiatry 2019, 86, 7-15. [CrossRef]

115. Luciana, M.; Bjork, J.M.; Nagel, B.J.; Barch, D.M.; Gonzalez, R.; Nixon, S.J.; Banich, M.T. Adolescent neurocognitive development and impacts of substance use: Overview of the adolescent brain cognitive development $(\mathrm{ABCD})$ baseline neurocognition battery. Dev. Cogn. Neurosci. 2018, 32, 67-79. [CrossRef]

116. Auchter, A.M.; Hernandez Mejia, M.; Heyser, C.J.; Shilling, P.D.; Jernigan, T.L.; Brown, S.A.; Tapert, S.F.; Dowling, G.J. A description of the ABCD organizational structure and communication framework. Dev. Cogn. Neurosci. 2018, 32, 8-15. [CrossRef] [PubMed]

117. Gutierrez-Rojas, C.; Pascual, R.; Bustamante, C. Prenatal stress alters the behavior and dendritic morphology of the medial orbitofrontal cortex in mouse offspring during lactation. Int. J. Dev. Neurosci. 2013, 31, 505-511. [CrossRef]

118. Mychasiuk, R.; Muhammad, A.; Kolb, B. Chronic stress induces persistent changes in global DNA methylation and gene expression in the medial prefrontal cortex, orbitofrontal cortex, and hippocampus. Neuroscience 2016, 322, 489-499. [CrossRef]

119. Poletti, S.; Vai, B.; Smeraldi, E.; Cavallaro, R.; Colombo, C.; Benedetti, F. Adverse childhood experiences influence the detrimental effect of bipolar disorder and schizophrenia on cortico-limbic grey matter volumes. J. Affect. Disord. 2016, 189, 290-297. [CrossRef] [PubMed]

120. Seidel, K.; Poeggel, G.; Holetschka, R.; Helmeke, C.; Braun, K. Paternal deprivation affects the development of corticotrophinreleasing factor-expressing neurones in prefrontal cortex, amygdala and hippocampus of the biparental Octodon degus. $J$. Neuroendocrinol. 2011, 23, 1166-1176. [CrossRef]

121. Assari, S.; Smith, J.; Mistry, R.; Farokhnia, M.; Bazargan, M. Substance Use among Economically Disadvantaged African American Older Adults; Objective and Subjective Socioeconomic Status. Int. J. Environ. Res. Public Health 2019, 16, 1826. [CrossRef] [PubMed]

122. Chen, E.; Paterson, L.Q. Neighborhood, family, and subjective socioeconomic status: How do they relate to adolescent health? Health Psychol. 2006, 25, 704-714. [CrossRef]

123. Moon, C. Subjective economic status, sex role attitudes, fertility, and mother's work. Ingu Pogon Nonjip 1987, 7, 177-196. [PubMed]

124. Assari, S.; Preiser, B.; Lankarani, M.M.; Caldwell, C.H. Subjective Socioeconomic Status Moderates the Association between Discrimination and Depression in African American Youth. Brain Sci. 2018, 8, 71. [CrossRef] [PubMed]

125. Boe, T.; Petrie, K.J.; Sivertsen, B.; Hysing, M. Interplay of subjective and objective economic well-being on the mental health of Norwegian adolescents. SSM Popul. Health 2019, 9, 100471. [CrossRef]

126. Wright, C.E.; Steptoe, A. Subjective socioeconomic position, gender and cortisol responses to waking in an elderly population. Psychoneuroendocrinology 2005, 30, 582-590. [CrossRef]

127. Ye, Z.; Wen, M.; Wang, W.; Lin, D. Subjective family socio-economic status, school social capital, and positive youth development among young adolescents in China: A multiple mediation model. Int. J. Psychol. 2020, 55, 173-181. [CrossRef]

128. Ursache, A.; Noble, K.G.; Blair, C. Socioeconomic Status, Subjective Social Status, and Perceived Stress: Associations with Stress Physiology and Executive Functioning. Behav. Med. 2015, 41, 145-154. [CrossRef]

129. Senn, T.E.; Walsh, J.L.; Carey, M.P. The mediating roles of perceived stress and health behaviors in the relation between objective, subjective, and neighborhood socioeconomic status and perceived health. Ann. Behav. Med. 2014, 48, 215-224. [CrossRef]

130. Manuck, S.B.; Phillips, J.E.; Gianaros, P.J.; Flory, J.D.; Muldoon, M.F. Subjective socioeconomic status and presence of the metabolic syndrome in midlife community volunteers. Psychosom. Med. 2010, 72, 35-45. [CrossRef]

131. Barch, D.; Pagliaccio, D.; Belden, A.; Harms, M.P.; Gaffrey, M.; Sylvester, C.M.; Tillman, R.; Luby, J. Effect of Hippocampal and Amygdala Connectivity on the Relationship Between Preschool Poverty and School-Age Depression. Am. J. Psychiatry 2016, 173, 625-634. [CrossRef]

132. Finn, A.S.; Minas, J.E.; Leonard, J.A.; Mackey, A.P.; Salvatore, J.; Goetz, C.; West, M.R.; Gabrieli, C.F.O.; Gabrieli, J.D.E. Functional brain organization of working memory in adolescents varies in relation to family income and academic achievement. Dev. Sci. 2017, 20. [CrossRef]

133. Brody, G.H.; Yu, T.; Nusslock, R.; Barton, A.W.; Miller, G.E.; Chen, E.; Holmes, C.; McCormick, M.; Sweet, L.H. The Protective Effects of Supportive Parenting on the Relationship between Adolescent Poverty and Resting-State Functional Brain Connectivity during Adulthood. Psychol. Sci. 2019. [CrossRef]

134. Clark, U.S.; Miller, E.R.; Hegde, R.R. Experiences of Discrimination Are Associated With Greater Resting Amygdala Activity and Functional Connectivity. Biol. Psychiatry Cogn. Neurosci. Neuroimaging 2018, 3, 367-378. [CrossRef] [PubMed]

135. Assari, S. Family Socioeconomic Position at Birth and School Bonding at Age 15; Blacks' Diminished Returns. Behav. Sci. 2019, 9 , 26. [CrossRef] [PubMed]

136. Assari, S.; Caldwell, C.H.; Mincy, R.B. Maternal Educational Attainment at Birth Promotes Future Self-Rated Health of White but Not Black Youth: A 15-Year Cohort of a National Sample. J. Clin. Med. 2018, 7, 93. [CrossRef] [PubMed]

137. Assari, S.; Caldwell, C.H.; Mincy, R. Family Socioeconomic Status at Birth and Youth Impulsivity at Age 15; Blacks' Diminished Return. Children 2018, 5, 58. [CrossRef] [PubMed] 